\title{
Polycyclic Aromatic Hydrocarbons (PAHs) and some Trace metals in Yam, Cassava, Orange and Papaya from two Oil and Gas Flaring Impacted Communities in Southern Nigeria
}

\author{
*11 NWAICHI, EO; ${ }^{2}$ AGBAM, P; ${ }^{3}$ IWU, PI \\ ${ }^{1}$ University of Port Harcourt Port Harcourt Nigeria, *nodullm@yahoo.com \\ ${ }^{I}$ The University of Nottingham UK. *Corresponding author \\ ${ }^{2}$ University of Port Harcourt Port Harcourt Nigeria, proschino@ gmail.com \\ ${ }^{3}$ University of Port Harcourt Port Harcourt Nigeria, iwup@gmail.com
}

\begin{abstract}
The present investigation provides data on the levels of PAHs and trace nutrient elements in selected tubers (yam and cassava) and fruits (orange and papaya) harvested from oil impacted and gas flaring areas in Akalaolu and Ogale Niger Delta communities. PAHs and heavy metals concentrations were analysed by Gas Chromatography and Atomic Absorption Spectrometry. Akalaolu samples gave ( $\mathrm{mg} \mathrm{kg}^{-1} \mathrm{PAHs}$ ) 4.321, 2.934, 19.003 and 7.004 while Ogale samples gave 3.445, 3.200, 5.41, 0 and 5.021 for cassava, yam, papaya and orange respectively. All selected fruits and tubers collected from the two sites contained significantly decreased trace nutrient elements and signal deficiency conditions. These findings suggest that study food crops from exposed areas are markedly contaminated by carcinogenic PAHs and may pose public nutrition and health concerns. Also, determination of trace nutrient elements in papaya at contaminated sites showed that papaya markedly accumulates metals in response to contamination. CJASEM https://dx.doi.org/10.4314/jasem.v21i6.10
\end{abstract}

Keywords: PAHs levels; Hydrocarbon contaminant exposure; Food safety; Fruits and tubers.

Compounds originating from crude oil are mostly mineral oil, BTEX, PAHs, phenolic compounds, heavy metals (Kissane, 2009; Nwaichi et al. 2011), chloroform, total trihalomethane, phthalate esters and relatively small quantities of other materials such as oxygen, nitrogen, sulphur, salt, water and some trace metals.

PAHs constitute a broad class of environmentally persistent organic compounds that are now ubiquitous in both aquatic and terrestrial ecosystems (Shiaris, 1989; Nwaichi et al., 2014). Although PAHs are ubiquitous in nature, quantities from synthesis in terrestrial vegetation, microbial synthesis, and volcanic activity, are infinitesimal in comparison with those produced from forest and prairie fires and anthropogenic sources (EPA, 1980). Anthropogenic activities associated with significant production of PAHs include deposition especially from spillage of petroleum and petroleum products (Nwaichi et al., 2015), coke production in the iron and steel industry, catalytic cracking in the petroleum industry, production of carbon black, coil tar pitch, asphalt, heating and power generation, controlled refuse incineration, open burning, and emissions from internal combustion engines used in transportation. As a general rule, the lower molecular weight PAHs tend to be more volatile, soluble and relatively mobile in the environment (Ogali et al., 2007; Nwaichi et al., 2014). Susceptibility to oxidation and reduction, vapor pressure and solubility, that decrease logarithmically (Neff, 1979) all tend to decrease with increasing molecular weight. According to Nwaichi et al. (2016), the implication of these is that the various classes of PAHs can differ substantially in their effects on biological systems and behavior in the environment. For example the lower molecular weight compounds, with two or three aromatic rings, such as the naphthalenes, anthracenes and fluoranthenes tend to be the most acutely toxic, whereas the longer PAHs with four to seven rings, such as benzopyrenes, chrysene and coronene, are not acutely toxic but tend to be more carcinogenic (Neff, 1979; Futoma , 1981).

Iron, copper, zinc, manganese, cobalt, molybdenum, iodine, bromine, and selenium are important trace dietary elements, necessary for mammalian life. They are also called minor dietary elements, with "minor" referring to their amount, as opposed to their importance. Upwards movement along the food chain is established when herbivores pick up elements as they feed on plants that absorbed dissolved elements in soils. The dietary focus on chemical elements derives from a growing interest in supporting the biochemical reactions of metabolism with the required elemental components (Lippard and Berg, 1994). Appropriate intake levels of certain chemical elements have been demonstrated to be required to maintain optimal health. In his book, DeWayne (1993) described supplementation of body's chemical element when not adequately met by diet in the face of chronic or acute deficiencies arise from pathology, injury, perturbations, etc.

Ogale is an oil rich community in Eleme local government area of Rivers state. Ogale people are mainly farmers but oil spillage (largely due to pipeline vandalism), especially the one that occurred in 2009, and the attendant water pollution, has plaqued their soil and water environment (ETOP, 2011). 
Akalaolu is a Niger Delta community in Ahoada West Local Government Area in Rivers state Nigeria. Most persons are farmers and the region has experienced oil spill, and has a gas flaring stack lighting the dark night.

This study aims to determine the levels of Polycyclic Aromatic Hydrocarbons (PAHs) and some Trace metals in Yam, cassava, Orange and Papaya from Akala-olu and Ogale communities in the Niger Delta, Nigeria

\section{MATERIALS AND METHODS}

Three replicate fruits (orange and papaya) and tuber (cassava and yam) samples were sourced from farmlands within $20 \mathrm{~m}$ to Gas flaring site and flow station in Akalaolu and Ogale communities. Samples from Nsirimo, Umuahia - South Local Government Area in Abia State Nigeria, with no presence of crude oil or related activities, were included as control.

Sample collection: The fruits and tuber samples were harvested on the 1st of November, 2014 from all locations. The tuber samples were up-rooted with help of wooden shovel and knife while the fruits samples were plucked with go-to-hell. Collected samples were properly cleaned, packaged with a sample bag, labeled and sent to the laboratory (Anal Concept Ltd) for analysis. Chain of custody was kept in the laboratory.

Sample preparation for PAHs determination: Collected samples were washed in deionized water to remove dirt and were allowed about 5 minutes to dryup. Cassava, yam and pawpaw samples were peeled and sliced thinly before drying. All the sliced samples were dried in the drying oven at $60 \mathrm{oC}$ for 72 hours then cooled to ambient temperature and milled using mortar. The milled samples were stored in air - tight plastic containers until required for analysis. Orange samples were also peeled and the juice was collected from it carefully to avoid mix-up. All the orange juices were collected for extraction.

Analytical procedure (extraction method), For solid samples: In triplicates, $100 \mathrm{mg}$ of sample was weighed into clean extraction containers. Ten $(10 \mathrm{ml})$ of extraction solvent (pentane) was added into each and mixed thoroughly and allowed to settle. The mixture was carefully filtered into clean solvent rinsed extraction bottles, using filter paper fitted to Buchner funnels. The extractions were concentrated to $2 \mathrm{ml}$ and then transferred for clean-up/ separation.

For liquid samples: In replicates of three, $100 \mathrm{ml}$ of the orange juice were transferred into $100 \mathrm{ml}$ measuring cylinder and poured into the separating funnel. Ten $(10 \mathrm{ml})$ of the extraction solvent (dichloromethane, DCM) was added into the sample, the separating funnel was corked and shaken vigorously to homogenize the sample and then, the separating funnel was uncorked and allowed to settle. The mixture formed a layer; the orange juice goes up while the extracting solvent comes down. Then the separating funnel was opened gradually from the tap to collect the solvent which has some of the orange constituents. The extracts were carefully filtered using the filter paper containing sodium sulphate. The extract was concentrated to $2 \mathrm{ml}$ and then transferred for cleanup /separation.

Clean-up / separation: One centimeter $(1 \mathrm{~cm})$ of moderately packed glass wool was placed at the bottom of $10 \mathrm{~mm}$ ID x $250 \mathrm{~mm}$ long chromatographic column. A slury of $2 \mathrm{~g}$ activated silica gel in $10 \mathrm{ml}$ methylene chloride was prepared and placed into the chromatographic column. To the top of the column was added $0.5 \mathrm{~cm}$ of sodium sulphate and the column was rinsed with additional $10 \mathrm{ml}$ of methylene chloride. The column was pre-eluted with $10 \mathrm{ml}$ of DCM, and this was allowed to flow through the column for about 2 minutes until the liquid in the column was just above the sulphate layer. At once, $1 \mathrm{ml}$ of the extracted sample was transferred into the column and the extraction bottle was rinsed with $1 \mathrm{ml}$ DCM and added to the column as well. The stopclock of the column was opened and the eluant was collected with a $10 \mathrm{ml}$ graduated cylinder. Just prior to exposure of the sodium sulphate layer to air, pentane was added to the column in $1-2 \mathrm{ml}$ increments. Accurately measured volume of $8-10 \mathrm{ml}$ of the eluant was collected and was labeled aliphatic.

Gas chromatographic analysis: The concentrated aliphatic fractions were transferred into labeled glass vials with rubber caps for GC (HP 5890 series 11) analysis. One microlitre $(1 \mu \mathrm{l})$ of the concentrated sample was injected by means of hypodermic syringe through a rubber septum into the column. Separation occurred as the vapour constituent partition between the gas and liquid phases and the sample was automatically (at a constant flow rate) detected by the FID detector whose response is dependent upon the composition of the vapour.

Sample preparation for metal analysis: Clean samples were dried and ignited in dishes and covered at $500^{\circ} \mathrm{C}$ for 30 minutes in the furnace. It was cooled, covered in a desiccator and weighed until a constant weight was obtained. Five grams of the sample was then weighed into the dish and allowed to burn slightly open for escape of gases until complete ashing i.e. whitish residue. Aqua regia digestion as reported by Nwaichi et al. (2014) was deployed for acid digestion of samples.

Obtained solution was marked up with distilled water in a clean $50 \mathrm{ml}$ flask. The concentrations of $\mathrm{Cu}, \mathrm{Zn}$, $\mathrm{Fe}$, and $\mathrm{Mn}$ in the filtrate were measured using ContrAA 300, Analytik Jena, Germany Atomic 
Absorption Spectrometry. Blank and refence material were included for accuracy and precision.

Statistical analysis: Means of triplicate date were subjected to ANOVA using SPSS version 13 and treatments were compared for statistical differences at 95\% confidence level.

\section{RESULTS AND DISCUSSION}

The results observed for total PAHs (Figure 1) and some trace elements in food samples from crude oil polluted land from Akala-olu and Ogale Communities are reported. The concentrations of PAHs in all samples but yam (Figure 1) from Akalaolu were higher than those of Ogale community and were significant.

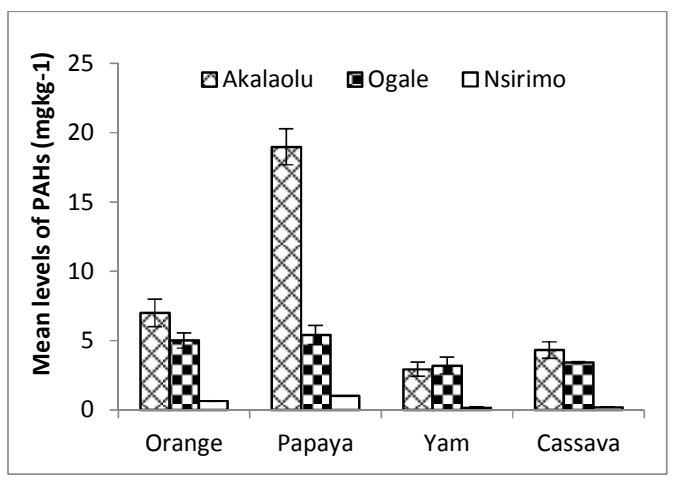

Fig 1: Mean levels of PAHs $\left(\mathrm{mg} \mathrm{kg}^{-1}\right)$ in studied food samples

Although observed PAHs concentrations were higher in yams from Ogale locations, results were not statistically significant ( $\mathrm{p} \leq 0.05)$. Again, all values obtained exceeded the European Union Limit of 0.2 $\mathrm{mg} \mathrm{kg}^{-1}$ (BFR, 2010). Certain isoforms of cytochrome p-450 are particularly involved in the metabolism of PAHs and related molecules, for this reason they were formerly called aromatic Hydrocarbon Hydrolases (AHHs). This enzyme is important in the metabolism of PAHs and in carcinogenesis produced by these agents (Roberk et al., 2003). They also reported higher levels of these enzymes in cells and tissues of exposed individuals, including pregnant women thus potentially implicating the quantities of metabolites of PAHs (some of which could be harmful) to which the foetus is exposed.

Benzo[b]fluoranthene PAH is one of the largest group of compounds with high concentrations in a typical soil sample contaminated with PAHs and was very abundant in food samples studied (Tables 1 to 4).

Detected benzo[a]anthracene, chrysene, benzo[b]fluoranthene, indeno[1,3-c,d]pyrene, dibenz[a,h]anthracene and benzo[k]fluoranthene
(Table 1) fall within the category of PAHs with the highest risk especially at prolonged exposure as reported by ATSDR (2007). Given marked levels of benzo[a]anthracene, chrysene, benzo[b] fluoranthene and benzo[k]fluoranthene implicated in carcinogenesis (Cal-EPA, 1994), it is feared that the population of people living in and around Akalaolu community may be predisposed to high risk of cancer due to long exposure to PAH compound through contaminated food crops as typified in Table 2 for yam samples. Elevated levels of strongly carcinogenic benzo (a) pyrene reported in Table 3, exceeded DPR intervention limit of $0.01 \mathrm{mg} \mathrm{kg}^{-1} \mathrm{dw}$ and EU limit of $0.2 \mathrm{mg} \mathrm{kg}^{-1}$ for food as reported by Nwaichi et al. (2014). Highest PAHs level of 19.003 $\mathrm{mg} \mathrm{kg}{ }^{-1}$ was recorded for papaya samples from Akalaolu locations (Table 4).
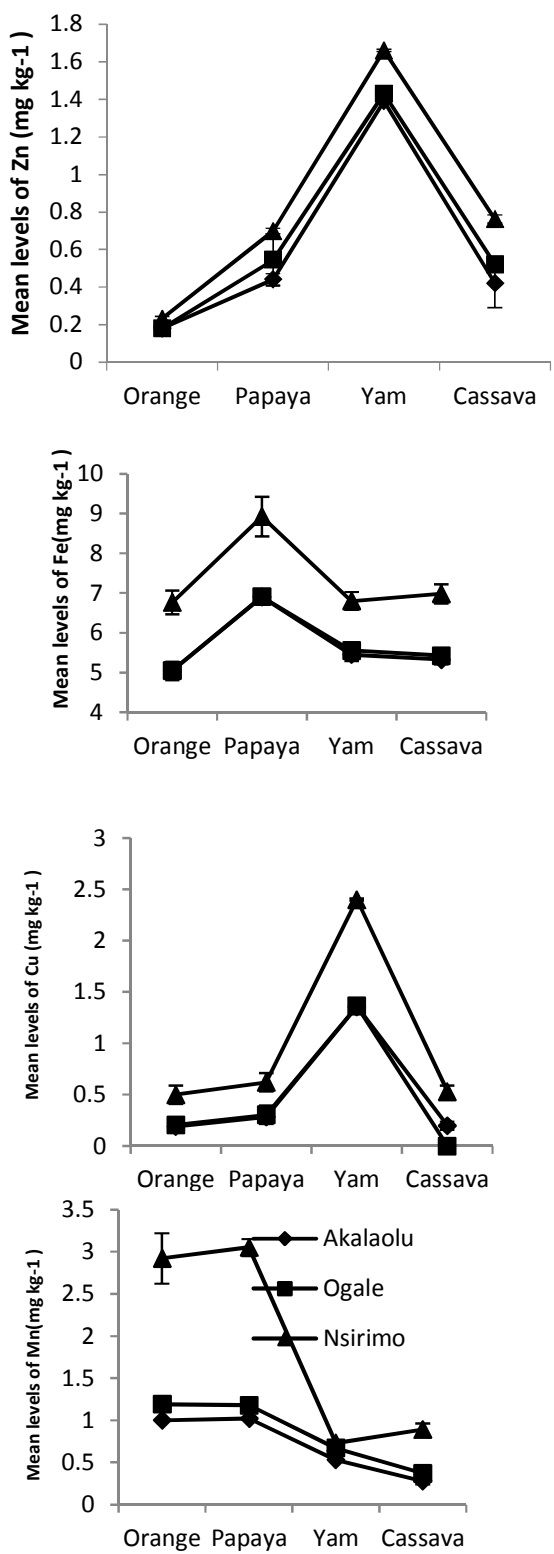

Fig 2: Mean concentrations of trace nutrient metals in study samples. Values are mean $\pm \mathrm{SE}, \mathrm{n}=3$ 
Table 1: Mean concentrations of PAHs (mg kg-1) in cassava samples

\begin{tabular}{llll}
\hline Contaminants & Nsirimo & Ogale & Akalaolu \\
\hline Acenaphthene & ND & ND & ND \\
Acenaphthylene & ND & ND & ND \\
Anthracene & ND & $0.107 \pm 0.001^{\mathrm{c}}$ & $0.181 \pm 0.009^{\mathrm{a}}$ \\
Benz(a)anthracene & ND & $0.143 \pm 0.009^{\mathrm{m}}$ & $0.198 \pm 0.009^{\mathrm{n}}$ \\
Benzo(a)pyrene & $\mathrm{ND}$ & $0.210 \pm 0.007^{\mathrm{a}}$ & $0.272 \pm 0.008^{\mathrm{b}}$ \\
Benzo(g,h,i)perylene & $\mathrm{ND}$ & $0.600 \pm 0.011^{\mathrm{a}}$ & $0.766 \pm 0.011^{\mathrm{b}}$ \\
Benzo(b)fluoranthene & $0.010 \pm 0.002^{\mathrm{a}}$ & $0.475 \pm 0.012^{\mathrm{b}}$ & $0.544 \pm 0.013^{\mathrm{c}}$ \\
Benzo(k)fluoranthene & $\mathrm{ND}$ & $0.780 \pm 0.014^{\mathrm{b}}$ & $0.820 \pm 0.015^{\mathrm{c}}$ \\
Chrysene & $0.010 \pm 0.001^{\mathrm{a}}$ & $0.091 \pm 0.006^{\mathrm{a}}$ & $0.097 \pm 0.010^{\mathrm{b}}$ \\
Dibenz(a,h)anthracene & $\mathrm{ND}$ & $0.007 \pm 0.001^{\mathrm{a}}$ & $0.030 \pm 0.004^{\mathrm{a}}$ \\
Fluoranthene & $\mathrm{ND}$ & $\mathrm{ND}$ & $\mathrm{ND}$ \\
Indeno(1,2,3-cd)pyrene & $\mathrm{ND}$ & $0.302 \pm 0.008^{\mathrm{a}}$ & $0.357 \pm 0.011^{\mathrm{b}}$ \\
Fluorene & $0.010 \pm 0.002^{\mathrm{a}}$ & $0.161 \pm 0.004^{\mathrm{b}}$ & $0.822 \pm 0.018^{\mathrm{c}}$ \\
Naphthalene & $0.002 \pm 0.001^{\mathrm{a}}$ & $0.208 \pm 0.003^{\mathrm{b}}$ & $0.047 \pm 0.004^{\mathrm{c}}$ \\
2-methylnaphthalene & $0.038 \pm 0.004^{\mathrm{a}}$ & $0.243 \pm 0.007^{\mathrm{b}}$ & $0.121 \pm 0.007^{\mathrm{b}}$ \\
Phenanthrene & $0.054 \pm 0.004^{\mathrm{a}}$ & $0.015 \pm 0.002^{\mathrm{b}}$ & $0.048 \pm 0.005^{\mathrm{c}}$ \\
Pyrene & $0.040 \pm 0.005^{\mathrm{a}}$ & $0.003 \pm 0.001^{\mathrm{b}}$ & $0.018 \pm 0.002^{\mathrm{c}}$ \\
Total & 0.204 & 3.445 & 4.321 \\
\hline
\end{tabular}

Table 2: Mean concentrations of PAHs $\left(\mathrm{mg} \mathrm{kg}^{-1}\right)$ in yam samples

\begin{tabular}{llll}
\hline \multicolumn{1}{c}{ Contaminants } & Nsirimo & Ogale & Akalaolu \\
\hline Acenaphthene & ND & ND & ND \\
Acenaphthylene & ND & ND & ND \\
Anthracene & ND & $0.102 \pm 0.008^{\mathrm{a}}$ & $0.012 \pm 0.002^{\mathrm{b}}$ \\
Benz(a)anthracene & ND & $0.132 \pm 0.009^{\mathrm{m}}$ & $0.080 \pm 0.006^{\mathrm{m}}$ \\
Benzo(a)pyrene & ND & $0.211 \pm 0.007^{\mathrm{a}}$ & $0.153 \pm 0.008^{\mathrm{a}}$ \\
Benzo(g,h,i)perylene & ND & $0.587 \pm 0.011^{\mathrm{a}}$ & $0.538 \pm 0.011^{\mathrm{a}}$ \\
Benzo(b)fluoranthene & ND & $0.482 \pm 0.011^{\mathrm{b}}$ & $0.355 \pm 0.011^{\mathrm{b}}$ \\
Benzo(k)fluoranthene & $0.002 \pm 0.001^{\mathrm{a}}$ & $0.773 \pm 0.012^{\mathrm{b}}$ & $0.605 \pm 0.014^{\mathrm{b}}$ \\
Chrysene & $0.008 \pm 0.001^{\mathrm{a}}$ & $0.081 \pm 0.006^{\mathrm{a}}$ & $0.038 \pm 0.003^{\mathrm{b}}$ \\
Dibenz(a,h)anthracene & $\mathrm{ND}$ & $0.018 \pm 0.003^{\mathrm{a}}$ & $0.019 \pm 0.002^{\mathrm{a}}$ \\
Fluoranthene & $\mathrm{ND}$ & $\mathrm{ND}$ & $\mathrm{ND}$ \\
Indeno(1,2,3-cd)pyrene & $\mathrm{ND}$ & $0.289 \pm 0.008^{\mathrm{a}}$ & $0.235 \pm 0.010^{\mathrm{a}}$ \\
Fluorene & $0.005 \pm 0.001^{\mathrm{a}}$ & $0.172 \pm 0.013^{\mathrm{b}}$ & $0.599 \pm 0.012^{\mathrm{c}}$ \\
Naphthalene & $0.002 \pm 0.001^{\mathrm{a}}$ & $0.141 \pm 0.005^{\mathrm{a}}$ & $0.034 \pm 0.004^{\mathrm{a}}$ \\
2-methylnaphthalene & $0.029 \pm 0.004^{\mathrm{a}}$ & $0.194 \pm 0.006^{\mathrm{a}}$ & $0.126 \pm 0.006^{\mathrm{a}}$ \\
Phenanthrene & $0.040 \pm 0.006^{\mathrm{a}}$ & $0.016 \pm 0.003^{\mathrm{a}}$ & $0.031 \pm 0.005^{\mathrm{c}}$ \\
Pyrene & $0.037 \pm 0.012 \mathrm{a}$ & $0.002 \pm 0.001^{\mathrm{b}}$ & $0.009 \pm 0.001^{\mathrm{b}}$ \\
Total & 0.161 & 3.200 & 2.937 \\
\hline
\end{tabular}

Without sufficient iron as it in in food from contaminated farmlands, consumers of such $\mathrm{Fe}$ - deficient foods cannot produce enough hemoglobin, a substance in red blood cells that makes it possible for them to carry oxygen to the body's tissues. This may result weakness, tiredness, and irritability and ultimately anemia.

This condition becomes more worrisome, given that our bodies are less efficient at absorbing non-heme iron from plant sources. Zinc helps to maintain sense of smell, healthy immune system, building proteins, enzymes, and DNA creation.

Zinc also helps in cell communication by functioning as a neurotransmitter and a deficiency can lead to stunted growth, diarrhea, impotence, hair loss, eye and skin lesions, impaired appetite, and depressed immunity (Whitehead, 2015).

Conversely, higher levels can lead to nausea, vomiting, loss of appetite, abdominal cramps, diarrhea, and headaches in the short term, and can disrupt absorption of copper and iron in the long term. Although study plant foods are not good dietary $\mathrm{Zn}$ sources as compared to most nuts, spinach and pumpkin seeds. Available $\mathrm{Zn}$ in harvested food materials was shown to depreciate with increasing soil contamination (Figure 2). Zinc was highest in yam $>$ papaya $>$ cassava $>$ orange.

Minimum composition of 1.4 documented in UK's official Table of food composition was met only in yams harvested from Ogale and Nsirimo (Figure 2). Similarly Copper is essential for bone and connective tissue production, and for coding specific enzymes that range in function from eliminating free radicals to producing melanin.

While their deficiency can lead to osteoporosis, joint pain, lowered immunity, and since copper is essential for the absorption of iron, anemia, over-consumption leads to cramps, diarrhea, and vomiting in the short term, and can lead to depression, schizophrenia, hypertension, senility, and insomnia in the long term (Whitehead, 2015). Copper in large amounts can even be poisonous.

The stomach needs to be acidic in order to absorb copper and thus antacids interfere with the absorption of copper, as do milk and egg proteins.

Yam samples from the contaminated sites, Ogale and Akalaolu, fell marginally below recommended range 1.4 to $11 \mathrm{mg}$ kg-1. It is noteworthy to document up to $43.24 \%$ and $43.17 \% \mathrm{Cu}$ decline in Akalaolu and Ogale respectively in relation to control.

Significant differences were found when food samples from the two exposed farms were compared to control for all study elements. However, differences obtained between exposed samples were not marked except for recorded Fe.

Measurement of trace nutrient elements in papaya at contaminated sites showed that papaya markedly accumulates metals in response to contamination. 
Table 3: Mean concentrations of PAHs $\left(\mathrm{mg} \mathrm{kg}^{-1}\right)$ in Orange samples

\begin{tabular}{llll}
\hline \multicolumn{1}{c}{ Contaminants } & Nsirimo & Ogale & Akalaolu \\
\hline Acenaphthene & $0.022 \pm 0.001^{\mathrm{a}}$ & $0.131 \pm 0.007^{\mathrm{b}}$ & $0.266 \pm 0.015^{\mathrm{c}}$ \\
Acenaphthylene & $\mathrm{ND}$ & $\mathrm{ND}$ & $\mathrm{ND}$ \\
Anthracene & $0.018 \pm 0.001^{\mathrm{a}}$ & $0.098 \pm 0.005^{\mathrm{c}}$ & $0.280 \pm 0.009^{\mathrm{c}}$ \\
Benz(a)anthracene & $\mathrm{ND}$ & $0.264 \pm 0.009^{\mathrm{m}}$ & $0.247 \pm 0.009^{\mathrm{m}}$ \\
Benzo(a)pyrene & $0.006 \pm 0.001^{\mathrm{a}}$ & $0.278 \pm 0.009^{\mathrm{a}}$ & $0.300 \pm 0.018^{\mathrm{a}}$ \\
Benzo(g,h,i)perylene & $\mathrm{ND}$ & $0.622 \pm 0.011^{\mathrm{a}}$ & $0.801 \pm 0.011^{\mathrm{b}}$ \\
Benzo(b)fluoranthene & $\mathrm{ND}$ & $0.619 \pm 0.011^{\mathrm{b}}$ & $0.611 \pm 0.010^{\mathrm{c}}$ \\
Benzo(k)fluoranthene & $0.017 \pm 0.001^{\mathrm{a}}$ & $0.796 \pm 0.014^{\mathrm{b}}$ & $0.988 \pm 0.015^{\mathrm{c}}$ \\
Chrysene & $0.047 \pm 0.001^{\mathrm{a}}$ & $0.418 \pm 0.014^{\mathrm{a}}$ & $0.520 \pm 0.020^{\mathrm{b}}$ \\
Dibenz(a,h)anthracene & $\mathrm{ND}$ & $0.032 \pm 0.003^{\mathrm{a}}$ & $0.248 \pm 0.0154^{\mathrm{b}}$ \\
Fluoranthene & $\mathrm{ND}$ & $\mathrm{ND}$ & $\mathrm{ND}$ \\
Indeno(1,2,3-cd)pyrene & $\mathrm{ND}$ & $0.388 \pm 0.017^{\mathrm{a}}$ & $0.500 \pm 0.013^{\mathrm{b}}$ \\
Fluorene & $0.031 \pm 0.001^{\mathrm{a}}$ & $0.251 \pm 0.024^{\mathrm{b}}$ & $0.899 \pm 0.018^{\mathrm{c}}$ \\
Naphthalene & $0.115 \pm 0.001^{\mathrm{a}}$ & $0.322 \pm 0.006^{\mathrm{b}}$ & $0.338 \pm 0.011^{\mathrm{c}}$ \\
2-methylnaphthalene & $0.178 \pm 0.004^{\mathrm{a}}$ & $0.361 \pm 0.014^{\mathrm{b}}$ & $0.329 \pm 0.0016^{\mathrm{b}}$ \\
Phenanthrene & $0.098 \pm 0.006^{\mathrm{a}}$ & $0.119 \pm 0.009^{\mathrm{b}}$ & $0.291 \pm 0.0011^{\mathrm{c}}$ \\
Pyrene & $0.120 \pm 0.012 \mathrm{a}$ & $0.222 \pm 0.014^{\mathrm{b}}$ & $0.233 \pm 0.011^{\mathrm{c}}$ \\
Total & 0.652 & 5.021 & 7.004 \\
\hline
\end{tabular}

Table 4: Mean concentrations of PAHs $\left(\mathrm{mg} \mathrm{kg}^{-1}\right)$ in Papaya sample

\begin{tabular}{llll}
\hline Contaminants & Nsirimo & Ogale & Akalaolu \\
\hline Acenaphthene & $0.027 \pm 0.003^{\mathrm{a}}$ & $0.129 \pm 0.007^{\mathrm{b}}$ & $0.549 \pm 0.015^{\mathrm{c}}$ \\
Acenaphthylene & ND & ND & ND \\
Anthracene & $0.038 \pm 0.004^{\mathrm{a}}$ & $0.108 \pm 0.005^{\mathrm{b}}$ & $0.502 \pm 0.019^{\mathrm{c}}$ \\
Benz(a)anthracene & ND & $0.277 \pm 0.009^{\mathrm{n}}$ & $0.282 \pm 0.009^{\mathrm{n}}$ \\
Benzo(a)pyrene & $0.006 \pm 0.001^{\mathrm{a}}$ & $0.288 \pm 0.0011^{\mathrm{a}}$ & $0.333 \pm 0.018^{\mathrm{b}}$ \\
Benzo(g,h,i)perylene & $\mathrm{ND}$ & $0.691 \pm 0.017^{\mathrm{a}}$ & $0.889 \pm 0.011^{\mathrm{b}}$ \\
Benzo(b)fluoranthene & $\mathrm{ND}$ & $0.625 \pm 0.021^{\mathrm{b}}$ & $0.801 \pm 0.019^{\mathrm{c}}$ \\
Benzo(k)fluoranthene & $0.027 \pm 0.001^{\mathrm{a}}$ & $0.797 \pm 0.014^{\mathrm{b}}$ & $1.658 \pm 0.015^{\mathrm{c}}$ \\
Chrysene & $0.124 \pm 0.001^{\mathrm{a}}$ & $0.438 \pm 0.014^{\mathrm{a}}$ & $0.854 \pm 0.020^{\mathrm{b}}$ \\
Dibenz(a,h)anthracene & $\mathrm{ND}$ & $0.131 \pm 0.008^{\mathrm{a}}$ & $0.421 \pm 0.0154^{\mathrm{b}}$ \\
Fluoranthene & $\mathrm{ND}$ & $\mathrm{ND}$ & $\mathrm{ND}$ \\
Indeno(1,2,3-cd)pyrene & $\mathrm{ND}$ & $0.389 \pm 0.011^{\mathrm{a}}$ & $0.693 \pm 0.013^{\mathrm{b}}$ \\
Fluorene & $0.047 \pm 0.006^{\mathrm{a}}$ & $0.349 \pm 0.024^{\mathrm{b}}$ & $2.849 \pm 0.018^{\mathrm{c}}$ \\
Naphthalene & $0.158 \pm 0.001^{\mathrm{a}}$ & $0.323 \pm 0.016^{\mathrm{b}}$ & $3.609 \pm 0.011^{\mathrm{c}}$ \\
2-methylnaphthalene & $0.209 \pm 0.004^{\mathrm{a}}$ & $0.362 \pm 0.014^{\mathrm{b}}$ & $4.823 \pm 0.016^{\mathrm{b}}$ \\
Phenanthrene & $0.155 \pm 0.006^{\mathrm{a}}$ & $0.169 \pm 0.009^{\mathrm{b}}$ & $0.422 \pm 0.011^{\mathrm{c}}$ \\
Pyrene & $0.210 \pm 0.012 \mathrm{a}$ & $0.242 \pm 0.014^{\mathrm{b}}$ & $0.318 \pm 0.015^{\mathrm{c}}$ \\
Total & 1.001 & 5.410 & 19.003 \\
\hline
\end{tabular}

Conclusion: This study has shown that trace nutrient element concentrations in food can vary with source soil quality. Thus care must be taken to collect samples from similar farms when evaluations are being made. Observed high molecular weight PAHs in all study fruits and tubers from test areas portends danger to the community locals and even wider targets given established trade. This is because they are less soluble and possess high tendency to interact with non-aqueous phases, become potentially unavailable for degradation by microbes, which tend to favorably degrade compounds dissolved in water.

Acknowledgments: The authors are grateful to Faith Owuala for assistance during community entry.

\section{REFERENCES}

ATSDR (2007) Agency for Toxic Substances and Disease Registry.Toxicological Profile for Lead, U.S. Department of Health and Human Services: Atlanta, U.S.A.

BFR (2010) Bundesinstitut für Risikobewertung. Federal Institute for Risk Assessment. Dossier submitted by Germany for carcinogenic PAH in consumer products. www.bfr.bund.de. Retrieved 10th October 2013.
Cal-EPA (1994) California Environmental Protection Agency.Memorandum, to Cal/EPA Departments, Boards, and Offices from Standards and Criteria Work Group, Office of Environmental Health Hazard Assessment. Subject: California Cancer Potency Factors. In: A methodology for using background PAHs to support remediation decisions (2000). ENVIRON Corporation Emeryville, California. p. 32

CDC (2013) Centers for Disease Control and Prevention. Polycyclic Aromatic Hydrocarbons Overview. http://www.cdc.gov/biomonito ring/Pyrene_BiomonitoringSu mmary.html. Retrieved 09 March 2016.

DeWayne, AH (1993) The Roles of Amino Acid Chelates in Animal Nutrition. Westwood: Noyes Publications.

EPA (1980). Ambient water quality criteria for polynuclear aromatic hydrocarbons. U.S. Environ. Protection Agency. Rep. 440/5-80-069. p193.

Etop, E (2011). Oil spill devastation in Eleme Community.

http://www.vanguardngr.com/2 011/12/as-oil-spill-devastateseleme-community-elders-seekquick-intervention/. Retrieved 20 February 2016.

Futoma, DJ (1981) Polycyclic aromatic hydrocarbons in water systems. CRC Press, Boca Raton, Fla

Kissane, K (2009). Fire power equalled 1500 atomic bombs. The age (Melbourne).

http://www.theage.com.au /national/fire-power-equalled15000-atomic-bombs20090521-bh7r.html?page $=1$. Retrieved 11 December 2015. 
Lippard, SJ; Berg, JM (1994). Principles of Bioinorganic Chemistry. Mill Valley, CA: University Science Books. p. 411.

Neff, JM (1979). Polycyclic Aromatic Hydrocarbons. In the Aquatic Environment: Sources, Fates and Biological Effects. Applied Sciences Publishers, London

Neff, JM (1985). Polycyclic Aromatic Hydrocarbons. In: Rand, A.M. and petrocelli; S.R. (eds). Fundamentals of Aquatic Toxicology. Hemisphere, New York. Pp 416-454.

Nwaichi, E. O., Chuku, LC; Ighoavwogan, E (2016). Polycylclic Aromatic Hydrocarbons and Selected Heavy Metals in Some Oil Polluted Sites in Delta State Nigeria. JEP.7, 1389-1410.

Nwaichi, EO; Frac, M; Nwoha, PA; Eragbor, P (2015). Enhanced phytoremediation of crude oil- polluted soil by four plant species: effect of inorganic and organic bioaugumentation. Intl J Phytorem. 17(12): 1253-1261.

Nwaichi, EO; Wegwu, MO; Nwosu, UL (2014). Distribution of selected carcinogenic hydrocarbon and heavy metals in an oilpolluted agriculture zone. EMAS. 186(12): 8697-8706.

Nwaichi, EO, Osuji, LC; Onyeike, EN (2011). Evaluation and Decontamination of Crude Oil-Polluted Soils using Centrosema pubescen Benth and Amendment-support options. Intl J Phytorem. 13 (4): 373 - 382.
Ogali, RE; Osuji, LC; Ayodele, O (2007). Acute Toxicity of the water soluble fraction of spent lubricating oil on the African catish clarias gariepinus.Chem. Biodiv. 4,2755-2765.

Roberk, KK; Darly, KG; Peter, AM; Victor, WR (2003). Harper's illustrated Biochemistry. 26th edition (Int'1 Edition)

Shiaris, MP (1989). Seasonal bitransformation of Naphthrene, and Benzo (a) pyrenein Vertical estuarine Sediment. Appl. Environ. Microbiol 55, 1931-1399

Whitehead, D. (2015). Top 10 Foods Highest in Zinc and Copper. www. Health Alicious Ness.com.retrieved 27 February 2016. 